\title{
Vegetative and reproductive development of balansa clover
}

\author{
D.P. MONKS and D.J. MOOT \\ Agriculture and Life Sciences Division, Lincoln University, PO Box 84, Lincoln \\ dave.monks@lincoln.ac.nz
}

\begin{abstract}
The rate of emergence, time of the first mainstem leaf appearance, phyllochron and branch initiation and inflorescence development were quantified for balansa clover (Trifolium michelianum). Thermal time requirement was $\sim 57$ degree days $\left({ }^{\circ} \mathrm{Cd}\right)$ for $50 \%$ final emergence, $111{ }^{\circ} \mathrm{Cd}$ for first leaf, $54{ }^{\circ} \mathrm{Cd}$ for phyllochron and $230^{\circ} \mathrm{Cd}$ for branch initiation all above a base temperature of $0^{\circ} \mathrm{C}$. Each inflorescence required $380^{\circ} \mathrm{Cd}$ from pollination to reach physiological maturity and a further $270{ }^{\circ} \mathrm{Cd}$ until all seeds were dark within pods, an indicator of harvest maturity. These values are transferable to different locations and can be used to define best management practices to maintain balansa clover in a grazed pasture or for seed production.
\end{abstract}

Keywords: base temperature, cardinal temperatures, growing degree days, thermal time, Trifolium michelianum

\section{Introduction}

Balansa clover (Trifolium michelianum) is an aerial flowering, small seeded annual pasture legume (Craig \& Ballard 2000). When grown in Canterbury and allowed to set seed in the establishment year it produced over $3 \mathrm{t} \mathrm{DM} / \mathrm{ha} / \mathrm{yr}$ for 3 years before the pasture needed to be closed to replenish the seedbank (Monks et al. 2008). However, the current cultivars available in New Zealand were bred for the Australian cropping environment, where plants are established without grass competition and experience low grazing pressure (Craig \& Ballard 2000). Developing management practices for New Zealand grazed pastures requires an understanding of vegetative and reproductive development of balansa clover plants.

Balansa clover produces a large number of small seeds $(\sim 1.2 \mathrm{mg} / \mathrm{seed})$ compared with the larger seeded ( $\sim 6.7 \mathrm{mg} / \mathrm{seed}$ ) subterranean clover (Trifolium subterraneum). A balansa clover seed that germinates and fails to survive is of a lower cost to the species than in a larger seeded species (Norman et al. 2005). However, each balansa clover seedling has a lower chance of survival. Because of this, balansa clover is most successful when sown alone or with little competition from existing plants. This was shown by its re-establishment in mixed pastures from year to year in a grazing experiment (Monks et al. 2008). This study coupled with data for flower initiation (Monks et al. 2010), aims to quantify the vegetative and reproductive development of balansa clover to define best management practices for its use in grazed pastures for seed production.

\section{Methods}

This paper describes a series of experiments in growth cabinets and in the field. Growth cabinets were used to measure vegetative development and a field experiment measured rate of emergence and reproductive development.

\section{Growth cabinet}

During five experiments, 50 hand-scarified 'Frontier' balansa clover seeds were sown in a randomised complete block design with four replicates into a bark and pumice potting mix with slow release fertiliser in $4.5 \mathrm{~L}$ plastic containers. Pots were re-randomised twice a week and watered at 3-5 day intervals. They were located on a slatted table $1.4 \mathrm{~m}$ high in a growth cabinet (Conviron PGV36, Winnipeg, Canada). The temperature was recorded with sensors (Thermistors KTY-110) at $10 \mathrm{~mm}$ depth for emergence and in the air for leaf development. Photoperiod was set for $8 \mathrm{~h}$ light and $8 \mathrm{~h}$ dark with $4 \mathrm{~h}$ transitions. Plants were handthinned as required to minimise inter-plant competition; a minimum of 12 plants remained. The mean daily temperature for each experiment is given in Table 1.

\section{Measurements}

The numbers of leaves on the mainstem and in the axil of a mainstem leaf were counted from 10 marked plants per pot at 3-5 day intervals until plants had at least 50 leaves. Leaves were considered to be emerged when the petiole was visible.

Table 1 The experiment number and mean temperature (24 h cycle) used in growth rooms for vegetative development observations of balansa clover.

\begin{tabular}{lccc}
\hline & \multicolumn{3}{c}{ Mean daily temperature (oC) } \\
\hline $\begin{array}{l}\text { Experiment } \\
\text { number }\end{array}$ & Air & $\begin{array}{c}10 \mathrm{~mm} \\
\text { below soil } \\
\text { surface }\end{array}$ & $\begin{array}{c}\text { Symbol } \\
\text { (see Fig- } \\
\text { ures) }\end{array}$ \\
\hline 1 & 6.8 & 11.5 & $\mathbf{\nabla}$ \\
2 & 10.5 & 15.0 & \\
3 & 15.6 & 19.6 & \\
4 & 20.8 & 23.8 & \\
5 & 25.5 & 27.3 & $\mathbf{\Delta}$ \\
\hline
\end{tabular}




\section{Analysis}

The mainstem leaf appearance interval (phyllochron) was determined by the slope of the linear relationship between leaf appearance rate and accumulated thermal time $\left({ }^{\circ} \mathrm{Cd} / \mathrm{leaf}\right)$ based on air temperature. Cardinal temperatures, including base temperature $\left(\mathrm{T}_{\text {base }}\right)$, optimum temperature $\left(\mathrm{T}_{\mathrm{opt}}\right)$ and maximum temperature $\left(\mathrm{T}_{\max }\right)$ and thermal time requirements $(\mathrm{Tt})$ were calculated using methods described by Angus et al. (1981). Thermal time was then re-calculated with $\mathrm{T}_{\text {base }}$ (y-intercept $)=0{ }^{\circ} \mathrm{C}($ Moot et al. 2000).

Initiation of branching was defined as when the total number of leaves exceeded the number of mainstem leaves by one. The total number of leaves was modelled using a standard exponential growth curve.

\section{Field experiment}

'Bolta' and 'Frontier' balansa clovers were sown at Lincoln University, Canterbury, New Zealand (43 $38^{\prime} \mathrm{S}, 172^{\circ} 28^{\prime} \mathrm{E}, 11 \mathrm{~m}$ a.s.1.) in a split-plot factorial design in randomised complete blocks with three replicates. The eight main plots were sowing date (Table 2) with two cultivars giving 48 plots. The soil is classified as a Templeton silt loam (Udic Ustochrept, USDA Soil Taxonomy) with $1.8-3.5 \mathrm{~m}$ of fine textured material overlying gravels (Cox 1978). Fertiliser was applied on 13 July 2005 following recommendations from a soil test. The experimental area was cultivated out of perennial ryegrass (Lolium perenne) pasture.

Bare seed without inoculum (sourced from Agricom Ltd., Ashburton, New Zealand) was sown at $6 \mathrm{~kg}$ viable seed/ha based on germination tests. Plots were $2.1 \times 6.0 \mathrm{~m}$ and drilled in $150 \mathrm{~mm}$ rows at a depth of $\leq 10 \mathrm{~mm}$ using an Øyjord cone seeder followed by chain harrows. Plots were then rolled with a Cambridge roller.

All plots received $35 \mathrm{~mm}$ of irrigation on 13 and 20 April 2006. All sown plots were sprayed on 28 October 2006 (post-flowering) with Pulsar ${ }^{\circledR}$ ( $200 \mathrm{~g} / \mathrm{l}$ bentazone and $200 \mathrm{~g} / \mathrm{l} \mathrm{MCPB}$ ) at $5 \mathrm{l} / \mathrm{ha}$ and Gallant ${ }^{\circledR}(100 \mathrm{~g} / \mathrm{L}$ haloxyfop) at $1.5 \mathrm{l} / \mathrm{ha}$ for control of broadleaf and grass weeds, particularly Poa anпua, respectively. Plots were not grazed.

Temperature was recorded with sensors (Thermistors KTY-110) at $10 \mathrm{~mm}$ depth for emergence and at $1.2 \mathrm{~m}$ in the air for leaf development.

\section{Measurements}

Total emerged seedlings (open cotyledons) were counted at 2-10 day intervals and the number of days to $50 \%$ emergence was calculated using a general logistic model. A numeric development scale was created to describe the progress of an individual inflorescence from bud visible to seed shatter (Table 3). Visible
Table 2 The sowing dates and dates inflorescences were tagged for balansa clover sown at Lincoln University, Canterbury, New Zealand.

\begin{tabular}{lcc}
\hline Sowing date & \multicolumn{2}{c}{ Tagging date } \\
& 'Bolta' & 'Frontier' \\
\hline 14 Oct 05 & & \\
1 Dec 05 & & \\
16 Jan 06 & & \\
8 Mar 06 & 9 Nov 06 & \\
27 Apr 06 & & \\
3 Jul 06 & & \\
30 Aug 06 06 \\
5 Feb 07 & 18 Dec 06 Dec 06 \\
\hline
\end{tabular}

Table 3 Visual scale outlining field observed development stages of balansa clover.

\begin{tabular}{ll}
\hline Stage & \\
1 & The plant has emerged \\
2 & Inflorescence bud is visible in the axil of a leaf \\
3 & Visible pollination \\
4 & $\begin{array}{l}\text { Full flower }-100 \% \text { of corollas have the stan- } \\
\text { dard unfolding from the wings }\end{array}$ \\
5 & Pods visible in the inflorescence \\
6 & $50 \%$ of pods are red $\left(\mathrm{R}^{\dagger}\right)$ \\
7 & $100 \%$ of seeds are dark red $(7.5 \mathrm{YR}(6 / 8)$ to \\
& $\left.5 \mathrm{YR}(2 / 3)^{\dagger}\right)$ \\
\hline
\end{tabular}

Note: ${ }^{\dagger}$ Munsell (1977) colour charts for plant tissues values.

pollination was said to have occurred at the first sign of browning on the corolla.

One hundred inflorescences per plot were tagged at the first sign of pollination (Stage 3) from the 27 April 2006, 30 August 2006 and 5 February 2007 sowing dates (Table 2). Every 4 days, starting on the day of marking, five of the 100 inflorescences were scored, harvested and dissected. Inflorescence dry weight was measured from plants sown on 27 April.

\section{Results}

\section{Vegetative development}

The cardinal temperatures for emergence in the field were a $\mathrm{T}_{\text {base }}$ of $\sim 2.2{ }^{\circ} \mathrm{C}$ and $\mathrm{T}_{\text {opt }}$ of $8.5{ }^{\circ} \mathrm{C}$ for both cultivars and a $\mathrm{T}_{\max }$ of $20.4( \pm 4.6)^{\circ} \mathrm{C}$ for 'Bolta' and $18.8( \pm 6.5){ }^{\circ} \mathrm{Cd}$ for 'Frontier'. The thermal time to $50 \%$ emergence was $59^{\circ} \mathrm{Cd}$ for 'Bolta' and $56{ }^{\circ} \mathrm{Cd}$ for 'Frontier' when the $\mathrm{T}_{\text {base }}$ was set to $0{ }^{\circ} \mathrm{C}$.

The number of mainstem leaves increased linearly with thermal time and was consistent among treatments when calculated on a thermal time basis (Fig. 1). Linear regression of the rate of first leaf appearance against mean $10 \mathrm{~mm}$ soil temperature showed 'Frontier' had a thermal time requirement of 
Figure 1 The number of mainstem (open symbols) and total number of leaves (closed symbols) for 'Frontier' balansa clover against accumulated thermal time from sowing from five growth room experiments set at five temperatures. Symbols are presented in Table 1. Note: The first arrow indicates the time of first leaf appearance and the second arrow indicates branch initiation. $\mathrm{T}_{\text {base }}=0^{\circ} \mathrm{C}$. Error bar indicates maximum standard error.

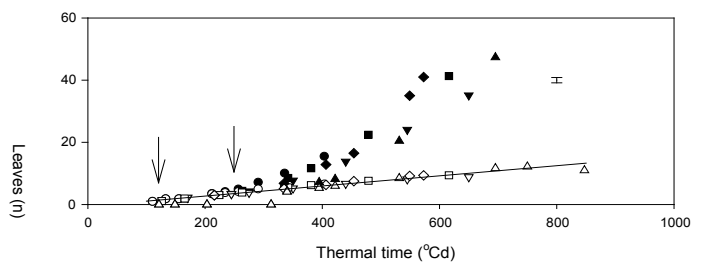

Figure 2 The inflorescence development stage of 'Bolta' $(\boldsymbol{\bullet}, \mathbf{\Delta})$ and 'Frontier' $(\odot, \bigcirc, \triangle)$ balansa clover against thermal time from marking (Stage 3) sown at different times in Canterbury, New Zealand. 5 February $(\odot), 27$ April $(\bullet, \bigcirc)$ and 30 August $(\boldsymbol{\Lambda}, \triangle)$. The dotted line represents Stage 7 , when all seeds were a dark colour. Note: $\mathrm{T}_{\text {base }}=0^{\circ} \mathrm{C}$. Error bar indicates maximum standard error.

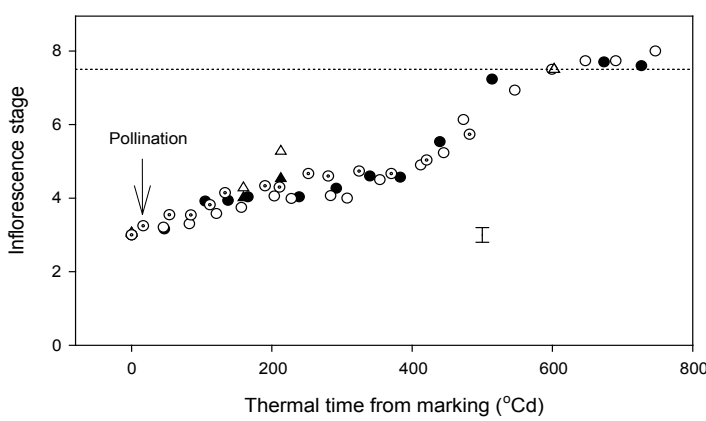

Figure 3 The average weight of individual inflorescences against thermal time from marking (Stage 3) for 'Bolta' $(\bullet)$ and 'Frontier' ( $($ ) balansa clover sown on 27 April 2006 in Canterbury, New Zealand. Arrow indicates physiological maturity. Note: $\mathrm{T}_{\text {base }}=0^{\circ} \mathrm{C}$. Error bar indicates maximum standard error.

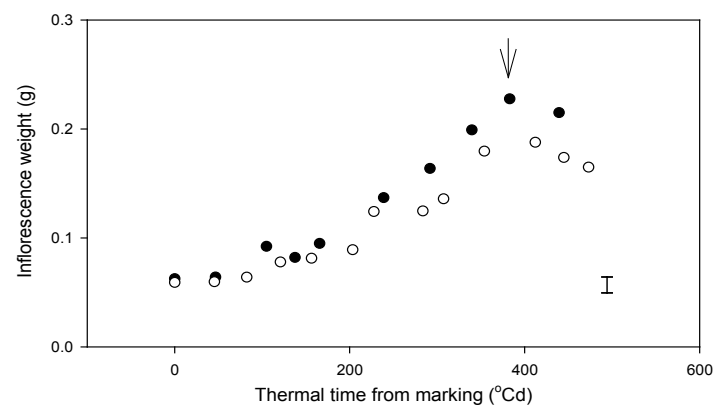

$111^{\circ} \mathrm{Cd}$ with $\mathrm{T}_{\text {base }}=0{ }^{\circ} \mathrm{C}$. The rate at which mainstem leaves appeared increased with mean temperature. However, a constant phyllochron of $54{ }^{\circ} \mathrm{Cd}$ was estimated and the thermal time for branch initiation was $230^{\circ} \mathrm{Cd}$.

\section{Reproductive development}

The duration from pollination until seeds were all a dark colour before shattering was $\sim 550{ }^{\circ} \mathrm{Cd}$ for 'Bolta' and 'Frontier' (Fig. 2) when analysed against thermal time $\left(\mathrm{T}_{\text {base }}=0^{\circ} \mathrm{C}\right)$. Inflorescences reached their maximum weight at $\sim 380{ }^{\circ} \mathrm{Cd}$ after marking (Fig. 3). This point of maximum weight coincided with visual Stage 6 (Table 3), when $50 \%$ of pods were red. This visual stage was therefore considered an indicator of physiological maturity.

\section{Discussion}

This work describes the annual life cycle of balansa clover by quantifying the rate and timing of emergence, leaf appearance and reproductive development. By relating development to thermal time, these data can be used to provide management recommendations beyond the experimental location. It also allows comparison of the vegetative and reproductive development of balansa clover with other pasture species.

Balansa clover required at least $100{ }^{\circ} \mathrm{Cd}$ less thermal time to emerge, produce the first mainstem leaf and initiate secondary branching than subterranean clover or the small seeded $(0.33 \mathrm{mg} / \mathrm{seed})$ adventive annual suckling clover (Trifolium dubium) (Lonati et al. 2009). Despite its rapid emergence, when sown in binary mixtures with cocksfoot, balansa clover consistently contributed less dry matter than subterranean clover (Mills et al. 2008). Small-seeded, annual species like balansa clover, which rapidly colonise bare soil, are more susceptible to competition for light and other resources than established perennial species (Fenner 1978). This, coupled with the ability of balansa clover to produce leaves more rapidly than the competing species, conveys a competitive advantage under grazing, especially during establishment, when all pasture components are maintained at an even height. This quantifies the advice from Australia to continuously graze balansa clover during establishment (Craig \& Ballard 2000). In a more intensive New Zealand system, this would take the form of short, frequent rotational grazing beginning once secondary branching has occurred, at about $230^{\circ} \mathrm{Cd}$ or $15-20$ days after emergence in autumn. Emergence of the fifth leaf is the first sign of branching. In the field, it is recommended to prepare the grass-dominant pasture with a 'clean-up' graze in summer to allow space for the annual balansa clover to re-establish (Monks et al. 2008). 
As a seed crop, balansa clover should be harvested after it is physiologically mature but before it shatters. That is, between 380 and $550{ }^{\circ} \mathrm{Cd}$ after peak flowering or between $\sim 25$ and 40 days in Canterbury (end of November for 'Bolta'). Half of the seed pods in each inflorescence will have changed from green to yellow/ red. Similarly, animals could be re-introduced to the pasture beyond this point to graze the standing hay and spread the seed in their faeces (Squella \& Carter 1996).

This work highlights the need to generate bare space before the autumn rain for balansa clover to emerge and produce leaves. The rapid rate of leaf appearance for balansa clover suggests leaf removal by grazing animals would have less impact on light interception than with other annual species. In addition, this work gives an appropriate harvest window to maximise seed yield for herbage seed producers

\section{ACKNOWLEDGEMENTS}

D.P. Monks acknowledges the financial assistance received for his $\mathrm{PhD}$ and in preparation of this paper from Meat \& Wool New Zealand Ltd (through their Pasture 21 programme), Tertiary Education Commission, C. Alma Baker Trust and Lincoln University.

\section{REFERENCES}

Angus, J.F.; Cunningham, R.B.; Moncur, M.W.; Mackenzie, D.H. 1981. Phasic development in field crops. 1. Thermal response in the seedling phase. Field Crops Research 3: 365-378.

Cox, J.E. 1978. Soils and agriculture of part Paparua County, Canterbury, New Zealand. New Zealand Soil Bureau Bulletin 34: 128.

Craig, A.D.; Ballard, R.A. 2000. Balansa clover (Trifolium michelianum) - a forage legume for temperate pastures. Cahiers Options Mediterraneennes 45: 177-180.

Fenner, M. 1978. Susceptibility to shade in seedlings of colonizing and closed turf species. New Phytologist 81: 739-744.
Lonati, M.; Moot, D.J.; Aceto, P.; Cavallero, A.; Lucas, R.J. 2009. Thermal time requirements for germination, emergence and seedling development of adventive legume and grass species. New Zealand Journal of Agricultural Research 52: 17-29.

Mills, A.; Smith, M.C.; Lucas, R.J.; Moot, D.J. 2008. Dryland pasture yields and botanical composition over 5 years under sheep grazing in Canterbury. Proceedings of the New Zealand Grassland Association 70: 37-44.

Monks, D.P.; Moot, D.J.; Scott, W.R. 2010. Photoperiod affects the flowering time of field sown balansa clover. Crop \& Pasture Science (In Press).

Monks, D.P.; Moot, D.J.; Smith, M.C.; Lucas, R.J. 2008. Grazing management of balansa clover for regeneration in a cocksfoot pasture. Proceedings of the New Zealand Grassland Association 70: 233-238.

Moot, D.J.; Scott, D.J.; Roy, A.M.; Nicholls, A.C. 2000. Base temperature and thermal time requirements for germination and emergence of temperate pasture species. New Zealand Journal of Agricultural Research 43: 15-25.

Munsell, A.H. 1977. Munsell color charts for plant tissues. 2nd edition. Macbeth Division of Kollmorgen Corporation. Baltimore, USA.

Norman, H.C.; Cocks, P.S.; Galwey, N.W. 2005. Annual clovers (Trifolium spp.) have different reproductive strategies to achieve persistence in Mediterranean-type climates. Australian Journal of Agricultural Research 56: 33-43.

Squella, F.; Carter, E.D. 1996. The significance of seed size on survival of some annual clover seeds in sheep pastures of South Australia.pp. 510-513.In: Proceedings of the 8th Australian Agronomy Conference, 30 January - 2 February, 1996. Toowoomba, Australia. Australian Society of Agronomy Inc. 